\title{
SCHOENOPLECTUS HALLII, S. SAXIMONTANUS, AND THE PUTATIVE $S$. HALLII $\times S$. SAXIMONTANUS HYBRID: OBSERVATIONS FROM THE WICHITA MOUNTAINS WILDLIFE REFUGE AND THE FORT SILL MILITARY RESERVATION $2002-2010$
}

\author{
Marian Smith \\ Southern Illinois State University \\ Edwardsville, IL 62025 \\ msmith@siue.edu
}

\author{
Paul M. McKenzie \\ U.S. Fish and Wildlife Service \\ 101 Park DeVille Drive, Suite A \\ Columbia, MO 65203
}

Keywords: Schoenoplectus, hybridization, management

\begin{abstract}
Schoenoplectus hallii, S. saximontanus, and the putative $S$. hallii $\times S$. saximontanus hybrid are obligate wetland sedges that occur in the sparsely vegetated margins of ponds, ditches or swales with fluctuating water levels. The species are amphicarpic and have easily identified differences between spikelet and basal achenes. We surveyed selected sites at the refuge in 2001, 2002, and 2007 - 2010, surveyed 4 sites on the Fort Sill Military Reservation in 2009 and 2010, and collected voucher specimens from all populations. Scanning Electron Microsope (SEM) photographs of spikelet and basal achenes indicate distinct morphological differences between species and the presence of "winged" ridges on S. saximontanus. Field observations indicated that populations at all sites vary in size and species distribution annually, and that both parental species appeared to be declining in number. We concluded that in populations where $S$. hallii and S. saximontanus co-occur, hybridization may be a threat to one or both parental species. The distribution of achenes by waterfowl and ungulates indicates that management to prevent establishment of mixed populations, and therefore hybridization, is not practical. We recommend that $S$. hallii be evaluated for federal listing under the Endangered Species Act, a range-wide assessment be completed for $S$. saximontanus, and that all sites with mixed populations should be examined for the presence of hybrids.

\section{INTRODUCTION}

Schoenoplectus hallii (A. Gray) S.G. Sm. and $S$. saximontanus (Fernald) Raynal are sedge species that were once thought to be separated geographically, with S. hallii present in the Midwest and eastern U. S. and $S$. saximontanus largely confined to the West (Gleason and Cronquist 1991, Beatty et al. 2004). Schoenoplectus hallii has a global ranking of G2 (imperiled). It is listed as "critically imperiled" in eight of the 12 states in which it occurs (NatureServe 2010) and as "imperiled" or "vulnerable" in three

other states. Herbarium records indicate that it had been reported from Georgia and Massachusetts prior to 1981 (McKenzie et al. 2007), but those populations are thought to have been extirpated (NatureServe 2010, McKenzie et al. 2007). Schoenoplectus saximontanus has a global ranking of G5 (secure) (NatureServe 2010), but it is listed as "critically imperiled" in British Columbia as well as in seven of the 12 states where it occurs. It has been reported from two states in Mexico (Flora of North America 2002). Throughout its range, $S$. saximontanus is considered to be an uncommon species
\end{abstract}


whose distribution is scattered (Flora of North America 2002).

Schoenoplectus hallii and S. saximontanus are obligate wetland species that have similar habitat requirements: most often sandy, rocky, or gravelly soil, occasionally clay, around the margins of ponds, ditches and swales with fluctuating water levels, and a scarcity of other plants as competitors (Flora of North America 2002, McKenzie et al. 2007). They most commonly complete their life cycle as annuals, but short-lived perennials have been reported from Texas (O'Kennon and McLemore 2004). Both species have 2-3 small basal leaves and tufted stems $\sim 4-40 \mathrm{~cm}$ long with small, inconspicuous rhizomes. The species are amphicarpic (having two distinct types of achenes), with numerous inflorescences on aerial stems containing perfect flowers and occasional, pistillate flowers enclosed in a leaf sheath at the plant base. It is difficult to distinguish between the species from vegetative characteristics alone. Achenes of $S$. hallii are 2-sided, and flowers have 2 lobed styles; whereas, achenes of $S$. saximontanus are distinctly 3 -sided, and flowers have 3-lobed styles (Flora of North America 2002). Achenes of both species have transverse ridging, and Magrath (2002) reported that the ridges on $S$. saximontanus were "winged;" whereas, those on $S$. hallii were smooth. This character had not been reported prior to his 2002 publication.

Both species have been reported from five states (KS, MO, NE, OK, and TX) (O'Kennon and McLemore 2004, McKenzie et al. 2007, NatureServe 2010); however, only Oklahoma (Magrath 2002), Kansas (C. Freeman, pers. comm. 2006), and Texas (Bob O'Kennon, pers. comm. 2007) have sites with mixed populations (Magrath 2002, Smith et al. 2004). Although S. saximontanus occurs in eight counties in OK, it only co-occurs with $S$. hallii in Comanche County (Oklahoma Vascular Plant Database 2006). In 2000, 134 sites at the Wichita Mountains Wildlife Refuge
(WMWR) in Comanche County were surveyed for $S$. hallii and $S$. saximontanus by Dr. Larry Magrath and personnel from the refuge (Magrath 2002). In August 2001, M. Smith and P. Mettler-Cherry re-examined the population sites surveyed by Magrath in 2000, and in subsequent years, 2002 and 2007 - 2010, the authors conducted surveys of selected sites at the refuge and Fort Sill Military Reservation (FSMR).

During the 2001 survey, M. Smith noted what appeared to be plants containing achenes that were intermediate between the two species, i.e., some appeared to be 2sided like those of $S$. ballii, except the usually flat or convex side contained a conspicuous bulge, and the achenes often had the "winged" appearance reported by Magrath (2002). Some plants had both 2 and 3 -sided achenes, some with, and some without "winged ridges." Other individuals produced only a few viable-looking achenes, with the majority of inflorescences bearing a preponderance of aborted achenes. Smith interpreted these anomalies as suggestive of hybridization between $S$. ballii and $S$.

saximontanus.

The objectives of this report are to discuss the results of a seed bank study for three sites conducted in 2001; to provide photographic documentation of the wingedridge appearance of $S$. saximontanus achenes reported by Magrath (2002); to summarize field observations made during visits to WMWR in 2002 and 2007 - 2010 and FSMR in 2009 and 2010; and to discuss the presence of putative hybrids of $S$. hallii and S. saximontanus and potential conservation concerns associated with hybridization among rare species.

Botanical nomenclature listed in this report follows Yatskievych and Turner (1990) except for Marsilea vestita which follows Diggs et al. (1999), Eleocharis coloradoensis which follows Smith (Flora of North America 2002), and Eleocharis ovata which follows Yatskievych (1999). 


\section{CHARACTERISTICS OF SPIKELET AND BASAL ACHENES}

In July 2001, spikelet and basal achenes were collected from individuals of $S$. hallii and S. saximontanus for Scanning Electron Microscopy (SEM) examination of achene surfaces and cross-sectional shape. Seeds were mounted onto aluminum stubs using double-stick transfer tabs (Electron Microscopy Sciences) and examined with a Hitachi S2460N variable pressure SEM at $30 \mathrm{kV}$ and $20 \mathrm{~Pa}$ pressure. Images were digitally recorded using a Noran Voyager III interface. For achene cross-sectional views, plastic blocks containing embedded specimens were sectioned until a transverse median section was obtained.

Both species exhibit transverse ridges (Figure $1 \mathrm{a}-\mathrm{h}$ ) as described in Flora of North America (Flora of North America 2002) and Flora of the Great Plains (Great Plains Flora Association 1986), except that the distinct difference between ridge morphology in $S$. hallii compared to $S$. saximontanus (see Figure $1 \mathrm{a}-\mathrm{h}$ ) is not discussed in either account. In Flora of the Great Plains (1986), the achenes of both species were described simply as having "transverse ridges," and no description of the amphicarpic (basal) achenes was provided. In Flora of North America (2002), spikelet achenes of both species were described as having "mostly sharp ridges." The basal achenes of $S$. hallii were described as "rugose with rounded edges," and this is confirmed by the SEMs in this article, but basal achenes of $S$. saximontanus were characterized in Flora of North America (2002) as "with obscure to evident horizontal ridges." 'The SEMs portrayed in Figure $1(\mathrm{a}-\mathrm{h})$ illustrate a distinctive species-difference in ridge shape on spikelet achenes and depict the basal achenes in $S$. saximontanus as having distinct, sharp ridges (see Figure $1 \mathrm{f}, \mathrm{h}$ ). Ridges on spikelet achenes in $S$. saximontanus, compared to $S$. hallii, are sharper and more elaborate in design, resulting in the "winged" appearance described by Magrath (2002). Ridges on basal achenes are subtle and incomplete in S. hallii (see Figure $1 \mathrm{e}, \mathrm{g}$ ), but prominent, more complete, and "winged" in $S$. saximontanus (see Figure $1 \mathrm{f}, \mathrm{h}$ ).
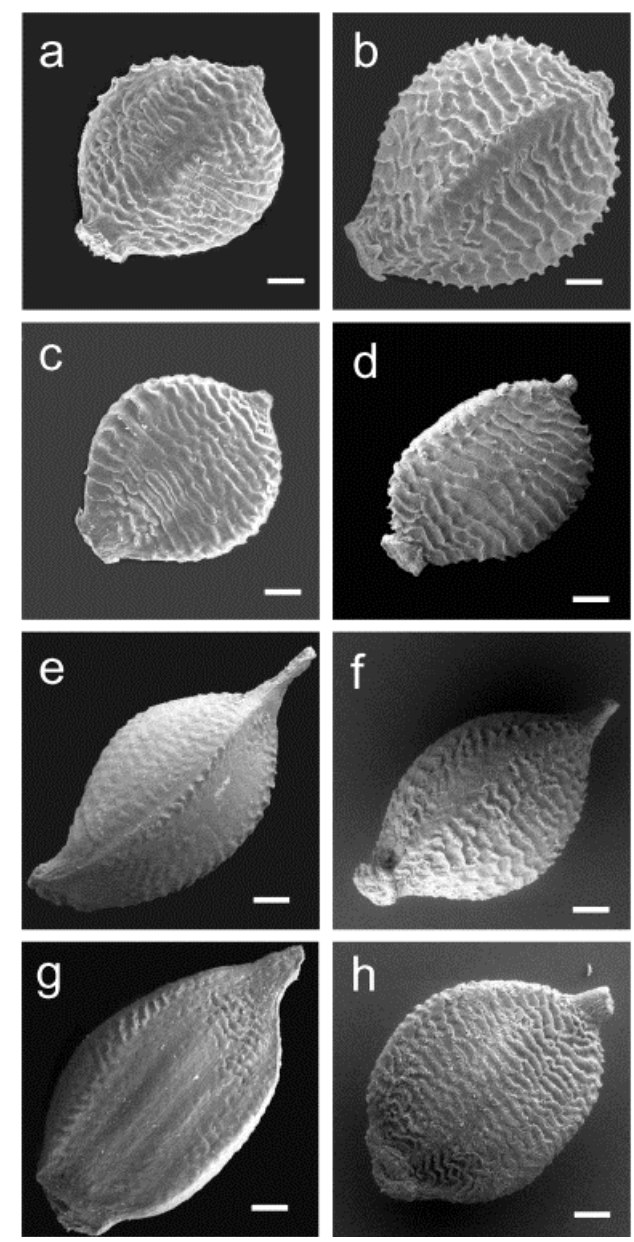

Figure 1 Surface views of front (a) and opposite (c) sides of spikelet achene of $S$. ballii and front (b) and opposite (d) sides of spikelet achene of S. saximontanus. Front (e) and opposite $(\mathrm{g})$ sides of basal achene of $S$. ballii and front (f) and opposite (h) sides of basal achene of $S$. saximontanus. Bars $=130$ $\mu \mathrm{m}$

Figure $2(\mathrm{a}-\mathrm{b})$ illustrates the often described cross-sectional shape of spikelet achenes: "plano-convex" (Flora of North America 2002) for S. hallii (see Figure 2 a) 
and "equilaterally, sharply trigonous," (Flora of North America 2002) for S. saximontanus (see Figure $2 \mathrm{~b}$ ). Magnified views of surface features (Figure $2 \mathrm{e}-\mathrm{h}$ ) in both types of achenes reinforce the differences in surface ridges between the two species shown in Figure 1. Ridges in S. ballii spikelet achenes (see Figure 2 e) are not sharp compared to the elaborate, sharp-tipped wings of $S$. saximontanus (see Figure $2 \mathrm{f}$ ). Surfaces of the basal achene of $S$. hallii (see Figure $2 \mathrm{~g}$ ) are mostly absent of ridges, but those of $S$. saximontanus (see Figure $2 \mathrm{~h}$ ) are prominent and elaborate, although not quite as sharp as in the spikelet achene.
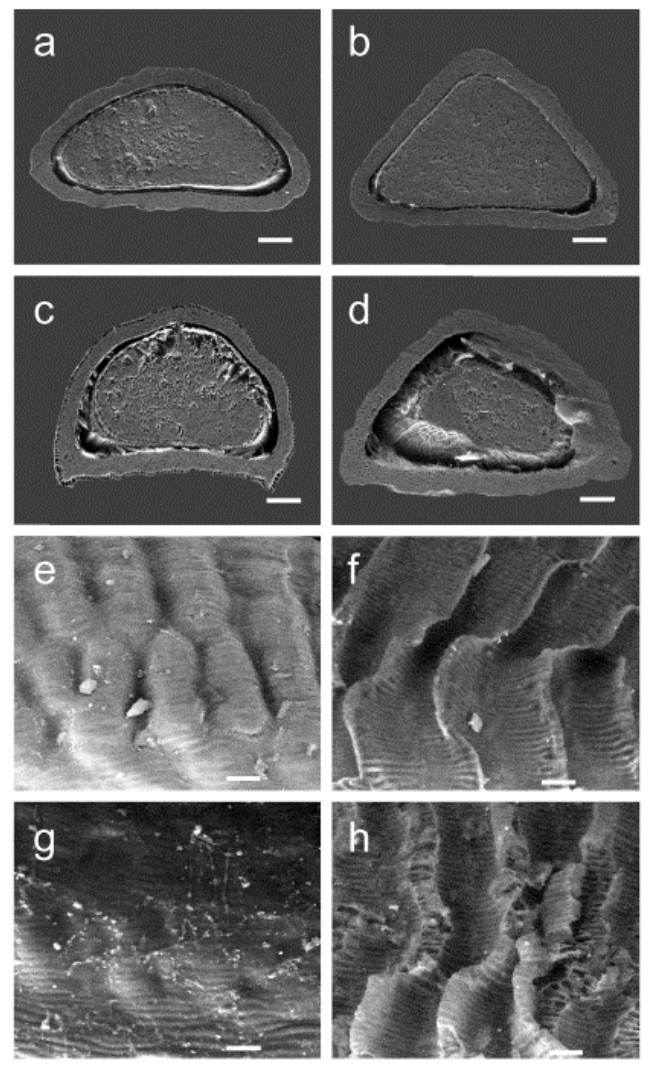

Figure 2 Cross-sectional views of spikelet (a) and basal (c) achenes of Schoenoplectus ballii and spikelet (b) and basal achenes (d) of S. saximontanus. Bars $=100 \mu \mathrm{m}$. Surface views of ridges of spikelet (e) and basal ( $\mathrm{g}$ ) achenes of $S$. hallii. Surface views of ridges of spikelet (f) and basal (h) achenes of $S$. saximontanus. Bars $=20 \mu \mathrm{m}$

\section{SOIL SEED BANK STUDY OF 2001}

In 2001, 15 plants were selected at each of three sites that had been included in Magrath's 2002 report (Boggy Flat, Quanah Parker Lake, and Hollis Lake at WMWR), and soil cores $(1.75 \mathrm{~cm} \times 8 \mathrm{~cm})$ were collected and separated into $2 \mathrm{~cm}$ sections. Achenes were recovered, counted, and separated by species and soil depth. Achenes were tested for viability as in Malone (1967); all achenes were viable. Eighty-six percent of the achenes were contained within the first $2 \mathrm{~cm}$ of the soil. All three sites had achenes of both species present in the soil; however, at the time of the site visit, extant populations at Boggy

Flats appeared to have only $S$. saximontanus and Hollis Lake had only $S$. hallii. Both species were present in the extant population at Quanah Parker. The presence of viable achenes of $S$. ballii and $S$. saximontanus in the soil at all three sites indicates either the undetected presence of both species during the site visit or the existence of both species at each site in previous years. As achenes of these species may remain dormant and viable for extended periods (McClain et al. 1997), their presence in the above-ground population might have occurred many years in the past and the current extant population may reflect an increase in one species and a decline or elimination of the other.

\section{FIELD OBSERVATIONS 2002, $2007-2010$}

In 2002, the authors visited selected sites at WMWR (Table) and specimens of Schoenoplectus were collected from five sites where $S$. hallii or $S$. saximontanus had been previously collected or reported (Magrath 2002). Field and laboratory observations indicated that the achenes of most spikelets of $S$. ballii and S. saximontanus were mature and exhibited characteristics typical for the species as described in the introduction; 
however, some achenes of the presumed $S$. ballii and S. saximontanus hybrids appeared to be abortive or malformed, while other putative hybrids produced both fully developed 2- and 3-sided achenes. Individuals of the putative hybrids were noticeably taller with longer inflorescences than either parent, and the spikelet scales were conspicuously brownish-orange (Smith et al. 2004). Specimens were sent to Dr. Alfred Schuyler, Dr. S. Galen Smith, and Dr. Anton Rezniceik for verification. The presence of a putative hybrid (McKenzie \#2028) was independently confirmed by each scientist based on morphological characters (Smith et al. 2004). Subsequent visits to WMWR and FSMR were made to collect material for a future genetic analysis.

The only site to be visited every year from 2007 - 2010 was Medicine Tank at WMWR; therefore, we will discuss some apparent trends in population size and species distribution at that site. In 2002, S. hallii was abundant and concentrated on the west shore of the pond while S. saximontanus was abundant on the south and east shore (see Table). The putative hybrid was scattered but present in various locations. In contrast, populations of all three species were abundant and widely distributed along the shore in 2007. In 2008, populations of S. hallii and S. saximontanus, although present at the site (see Table), appeared to be smaller and more restricted than in 2002 and 2007. As in 2007, S. hallii and S. saximontanus were scattered along the entire pond margin without any noticeable concentration at different shore edges; however, the putative $S$. hallii $\times S$. saximontanus hybrids were more abundant and concentrated along the northwest shore (see Table).

In 2009, the water level at Medicine Tank was lower than had been observed on previous visits, and there was a noticeable reduction in population size of $S$. ballii and S. saximontanus, especially the latter which was scattered and extremely rare. The putative hybrid was common and the population had expanded beyond the northwest shore (see Table). Schoenoplectus hallii was rare at Medicine Tank in 2010, and S. saximontanus, which had been present in previous years, was notably absent. Conversely, the putative hybrid was abundant (see Table) and had apparently overtaken habitat around the pond that had been previously occupied by $S$. hallii or $S$. saximontanus.

In addition to Medicine Tank, we visited three other sites in 2009 at WMWR, and water levels were lower at all of them than in previous years. Ponds that were composed mostly of hardened clay were lacking, or had very few, Schoenoplectus individuals (Ingram Pond and Rock Dam), but ponds that had rocks, cobble, and/or sand had healthy flowering and fruiting plants (Medicine Tank, Quanah Parker Lake), although in reduced numbers compared to 2007 and 2008 (see Table). No bulrushes were observed at two sites where S. saximontanus was found in 2007 (Boggy Flat and unnamed pond $\sim 1.5 \mathrm{mi}$ east, see Table). In 2010, we collected S. saximontanus from Grama Lake, which was the only time we documented any bulrush at this site during our visits between 2001 and 2010. Other sites were visited and vouchers were collected at WMWR from 2007 - 2010 as noted in the table.

We visited four sites at FSMR in 2009 and two sites in 2010 and documented the presence of $S$. hallii, S. saximontanus, and putative $S$. hallii $\times S$. saximontanus hybrids at the reservation in both years. In 2009, $S$. hallii was found at all four sites, and S. saximontanus and the putative hybrid were present at two (see Table). In 2010 S. hallii and $S$. saximontanus had disappeared from Pottawatomie Pond and the putative hybrid had increased in number (see Table). Schoenoplectus spp. observed at FSMR were all at ponds that had a sandy or gravelly shoreline. Our collections constitute the first documented records of $S$. hallii, $S$. 
saximontanus, and the putative hybrids from FSMR and confirm the predictions of Magrath (2002) that the two parent species would likely be discovered at Fort Sill.

\section{HABITAT AND PLANT ASSOCIATES}

Schoenoplectus ballii, S. saximontanus, and putative $S$. hallii $\times S$. saximontanus hybrids occurred along the edges of ponds and lakes at WMWR and at FSMR that had receding shorelines. Very little vegetation competed with the Schoenoplectus spp. in the narrow marginal areas along the water's edge. Although the majority of populations of Schoenoplectus occurred in sandy or gravelly/rocky soil, a few were found on clay substrates. Many sites were heavily grazed by elk, bison, or longhorn cattle, and the soil was significantly trampled by ungulates or disturbed by foraging feral hogs.

Plant associates varied widely from site to site and included the following species: Ammannia coccinea Rottb., Bacopa rotundifolia (Michx.) Wettst., Bergia texana (Hook.) Seub. ex Walp., Cyperus acuminatus Torr. \& Hook. ex Torr., C. difformis L., C. setigerus Torr. \& Hook., C. squarrosus L., Eclipta prostrata (L.) L., Eleocharis acicularis (L.) Roem. \& Schult., E. atropurpurea (Retz.) J. Presl. \& C. Presl., E. coloradoensis (Britt.) Gilly, E. ovata (Roth) Roem. \& Schult., E. parvula (Roem. \& Schult.) Link ex Bluff, Nees \& Schauer, Juncus spp., Justicia americana (L.) Vahl, Lindernia dubia (L.) Pennell, Marsilea vestita Hook. \& Grev., Panicum scoparium Lam., Paspalidium geminatum (Forssk.) Stapf., var. geminatum, Phyla nodiflora (L.) Greene, Pilularia americana A. Braun, Tribulus terrestris L., and Xanthium strumarium L.

\section{DISCUSSION}

We observed culms of $S$. saximontanus, $S$. ballii, and the putative hybrid flowering and producing viable fruit from July through mid-October, indicating that they are able to do so anytime during the growing season when conditions for germination and growth are favorable (Baskin et al. 2003). At all four sites where $S$. hallii and $S$. saximontanus occur in mixed populations, the putative hybrid was present (Medicine Tank, Quanah Parker Lake, Zania Pond, and Pottawatomie Pond) (see Table), suggesting that hybridization is a definite possibility in any mixed population. Soil cores collected in 2001 from Boggy Flat and Hollis Lake appeared to contain achenes of both $S$. hallii and $S$. saximontanus, but as hybrids had not been verified at the time the cores were processed, it is possible that hybrid seed might have been present. In any case, it is likely that in some years individuals of both species (and possibly those of the putative hybrid) may emerge at those sites in the future.

Schoenoplectus ballii and S. saximontanus cooccur at Rhodes Lake, TX where they are on opposite ends of the reservoir (Robert O’Kennon, pers. comm. Oct. 2007); however, the ease with which waterfowl may transport achenes for long distances (deVlaming and Proctor 1968; Powers et al. 1978) suggests that the species may form a mixed population in the near future. Historically, S. ballii and S. saximontanus were apparently allopatric and likely came in contact with one another via the muddy feet of migrating waterfowl, as suggested by McClain et al. (1997) and Beatty et al. (2004). It was postulated by Magrath (2002) that large herbivores such as bison and other animals were dispersal agents for achenes of $S$. hallii and $S$. saximontanus at WMWR. Our observations support the possibility of elk and bison as dispersal agents, as hoofprints of both were evident at every site. As neither elk nor bison are common at FSMR, we propose that achenes of the two species at the reservation are more likely to have been transported among ponds via waterfowl, white-tail deer, and feral hogs. Toni Hodgkins, naturalist at FSMR, reported that feral hogs equipped 
with radio transmitters were documented moving to and from the reservation and noted that 1200 pigs had been captured in less than a year (Toni Hodgkins, pers. comm. 2010).

There is an historical site in Kansas where $S$. hallii and S. saximontanus were known to be sympatric in 1997, but Craig Freeman at the University of Kansas examined the voucher specimens from the site in 2006 and did not note any evidence of hybridization (Craig Freeman, pers. comm. 2006). Nevertheless, it would be advisable to continue to monitor these areas in KS and TX to further assess the incidence of hybridization in mixed populations.

We suggest that when viewing live material in the field, or when examining dried voucher specimens, a thorough evaluation of multiple spikelets from different plants is necessary for reliable identification of plants collected from populations where $S$. hallii and $S$. saximontanus co-occur. Spikelets should be carefully examined for the presence of mixed style numbers, abortive achenes, or abnormally shaped, 2- or 3-sided achenes. Some spikelets that have achenes characteristic of one species may have an achene that would be better identified as the other species. Thus, the failure to examine multiple spikelets from different plants may result in a premature determination of specimens collected from mixed populations.

The presence of $S$. hallii $\times S$. saximontanus hybrids at WMWR and FSMR may threaten the long term persistence of $S$. ballii and S. saximontanus in $\mathrm{OK}$ and constitute a threat to the conservation of the species in North America. According to conservation geneticists, the possible dangers of hybridization are numerous and pose a serious threat to the survival of rare species that hybridize with a closely related congener (Levin et al. 1996). Although the extinction of rare species typically is attributed to environmental change that renders the habitat unsuitable (Harrison 1991; National Research Council 1995), hybridization may have a profound effect on the persistence of a species (Rieseberg 1991; Ellstrand 1992; Rieseberg and Linder 1999). Hybrids compete for space and resources with parental species and reduce the potential for plants to replace themselves, thereby inhibiting the growth of their populations - the lower the rate of population growth, the greater the potential for extinction in a variable environment (Menges 1992). The numerical disadvantage of a rare species is compounded by the proliferation of fertile hybrids (Rhymer and Symberloff 1996). If one of the species is rarer than the other, the addition of hybrids to a population containing congeners decreases the proportional representation of the less abundant parent. In time, backcrossing can result in the assimilation of the rare species whose genetic identity will become extinct, and, over evolutionary time, the DNA of the former rare species may be lost from the gene pool altogether (Rieseberg et al. 1996). In the case of S. hallii and $S$. saximontanus in $\mathrm{OK}$, both of which appear to be rare, it is possible that although much of the DNA of both species may survive, the two species may be subsumed into a new species with a new genetic identity.

\section{FUTURE ACTIONS}

Because of the impossibility of controlling achene dispersal-agents at WMWR and FSMR, it is unlikely that management to prevent hybridization is possible. We recommend, however, that monitoring of the populations of Schoenoplectus at WMWR and FSMR be continued to confirm or dismiss the importance of hybridization as a threat in the area.

Given the documented hybridization between $S$. hallii and $S$. saximontanus in 
Oklahoma and the identification of new threats to $S$. hallii in Illinois (McKenzie et al. 2010), the species should be re-evaluated as a possible candidate for federal listing under the Endangered Species Act. No range-wide status assessment exists for $S$. saximontanus, and as noted in the introduction, the species is critically imperiled in seven of the 12 states where it has been documented. We recommend that a thorough analysis of the distribution and size of populations of $S$. saximontanus be made, and that potential threats to the species be assessed. Further studies may provide evidence that this species may also warrant protection under the Endangered Species Act.

\section{ACKNOWLEDGMENTS}

The observations reported in this paper could not have been made without the help of a large number of friends and colleagues. We thank Dr. Paige Mettler-Cherry and Dr. Nancy Parker for their company during our many trips to Oklahoma, their help in the field, and their advice on Schoenoplectus issues in general. Sam Waldstein, former refuge manager, was essential to our project and, without his help during our first visit in 2001 our work at WMWR would not have been possible. Dr. Larry Magrath served as our inspiration to undertake this work, generously shared his observations from 2000, and allowed us to view the voucher specimens at the USAO herbarium. Robert O'Kennon of BRIT spent a day with us in pouring rain, cheerfully taking us to the Schoenoplectus sites he had recently discovered in north central Texas. Volunteer Donna Phillips took the time during our subsequent visits to WMWR to help us locate small ponds in the research area. At Fort Sill, FSMR biologist Toni Hodgkins enabled us to visit ponds and search for Schoenoplectus during our 2009 and 2010 visits to the Lawton area.

\section{LITERATURE CITED}

Baskin, C. C., J. M. Baskin, E. W. Chester, and M. Smith. 2003. Ethylene as a possible cue for seed germination of Schoenoplectus hallii (CYPERACEAE), a rare summer annual of occasionally flooded sites. American Journal of Botany 90:620-627.

Beatty, B. L., W. F. Jennings, and R. C. Rawlinson. 2004. Schoenoplectus hallii (Gray) S.G. Sm. (Hall's bulrush): a technical conservation assessment. Prepared for the USDA Forest Service, Rocky Mountain Region, Species Conservation Report. Peer review administered by Center for Plant Conservation, St. Louis, Missouri. deVlaming, V. and V. W. Proctor. 1968. Dispersal of aquatic organisms: Viability of seeds recovered from the droppings of captive killdeer and mallard ducks. American Journal of Botany 55:20-26.

Diggs, G. M. Jr., B. L. Lipscomb, M. D. Reed, and R. J. O'Kennon. 1999. Illustrated flora of north central Texas. Sida, Botanical Miscellany 16:1-1626.

Elstrand, N. C. 1992. Gene flow by pollen: Implications for plant conservation genetics. Oikos 63:77-93.

Flora of North America Editorial Committee, eds. 2002. Vol. 2. Magnoliophyta: Commelinidae (in part): Cyperaceae. Oxford University Press, New York.

Gleason, H. A. and A. Cronquist. 1991. Manual of V ascular Plants of Northeastern United States and Adjacent Canada, Ed. 2. New York Botanical Garden, Bronx.

Great Plains Flora Association. 1986. R. L. McGregor, Coordinator; T. M. Barkley, R. E. Brooks, and E. K. Schofield (eds.) Flora of the Great Plains. University Press of Kansas, Lawrence.

Harrison, S. 1991. Local extinction in a metapopulation context: An empirical evaluation. Biological Journal of Linnean Society 3-88. 
Levin, D. A., J. Francisco-Ortega, and R. K. Jansen. 1996. Hybridization and the extinction of rare plant species. Conservation Biology 10:10-16.

Magrath, L. K. 2002. Schoenoplectus hallii and S. saximontanus. 2000 Wichita Mountain Wildlife Refuge survey. Oklahoma Native Plant Record 2:54-62.

Malone, C. R. 1967. A rapid method for enumeration of viable seeds in soil. Weeds 15:381-382.

McClain, W. E., R. D. McClain, and J. E. Ebinger. 1997. Flora of temporary sand ponds in Cass and Mason counties, Illinois. Castanea 62:65-73.

McKenzie, P. M., S. G. Smith, and M. Smith. 2007. Status of Schoenoplectus ballii (Hall's bulrush) (Cyperaceae) in the United States. Journal Botanical Research Institute of Texas 1:457-481.

McKenzie, P. M., M. Smith, and T. Kelley. 2010. Observations of Hall's bulrush (Schoenoplectus hallii) (Cyperaceae) in Mason County Illinois in 2009. Transactions of Illinois State Academy of Science 103:97-108.

Menges, E. S. 1992. Stochastic modeling of extinction in plant populations. In: Fiedler and Jain, eds. Conservation Biology, pp. 253-275. Chapman and Hall, New York.

National Research Council. 1995. Science and the endangered species act. National Academy Press, Washington, DC.

NatureServe. 2010. NatureServe Explorer: An online encyclopedia of life [web application]. Version 5.0 NatureServe, Arlington, Virginia. Available at: http://www.natureserve.org/explorer. (accessed: Feb 2010)

O'Kennon, R. J. and C. McLemore. 2004. Schoenoplectus hallii (CYPERACEAE), a globally threatened species new for Texas. Sida 21:1201-1204.

Oklahoma Vascular Plant Database. 2006. http://www.coordinatesolutions.com/o vpd/ovpd.aspx. (accessed: Feb 2010)

Powers, K. D., R. E. Noble, and R. H. Chabreck. 1978. Seed distribution by waterfowl in southwestern Louisiana. Journal of Wildlife Management 42:598-605.

Rhymer, J. M. and D. Simberloff. 1996. Extinction by hybridization and introgression. Annual Review of Ecological Systems 27:83-109.

Rieseberg, L. H. 1991. Hybridization in rare plants: Insights from case studies in Cerocarpus and Helianthus. D. A. Falk and K. E. Holsinger, eds. In: Genetics and Conservation of Rare Plants, pp. 171-181. Oxford University Press, New York.

Rieseberg, L. H. and C. R. Linder. 1999. Hybrid classification: insights from genetic map-based studies of experimental hybrids. Ecology 80:361370.

Rieseberg, L. H., B. Sinervo, C. R. Linder, M. C. Ungerer, and D. M. Arias. 1996. Role of gene interactions in hybrid speciation: Evidence from ancient and experimental hybrids. Science 272:741645.

Smith, M., P. McKenzie, P. Mettler-Cherry, and S. G. Smith. 2004. A putative hybrid of Schoenoplectus saximontanus and S. ballii (CYPERACEAE) from Oklahoma. Sida 21:475-479.

Yatskievych, G. 1999. Steyermark's Flora of Missouri-Volume 1 - Revised ed. Missouri Department of Conservation, Jefferson City.

Yatskievych, G. and J. Turner. 1990. Catalogue of the Flora of Missouri. Monograph Systematic Botany, Missouri Botanical Garden 37:1-345. 
Table Schoenoplectus hallii (Sh), S. saximontanus (Ss), and putative hybrid (Hy) at Wichita Mountain Wildlife Refuge (WMWR) and Fort Sill

Military Reservation (FSMR) at selected sites: 2002, 2007-2010; Boggy Flat (BF), Elmer Thomas (ET), Engineer Pond (EP), Grama Lake (GL), Hollis Pond (HL), Ingram Pond (IP), Medicine Tank (MT), Pottawatomie Pond (PP), Quanah Parker Lake (QPL), Rock Dam (RD), Zania Pond (ZP)

\begin{tabular}{|c|c|c|c|c|c|}
\hline Date & Area & Site & $\begin{array}{l}\text { Species } \\
\text { collected }\end{array}$ & *Collection \# & Abundance \\
\hline \multirow[t]{7}{*}{ July 2002} & WMWR & HP & $\mathrm{Sh}$ & 2023 & $\sim 100$ flowering and fruiting culms \\
\hline & & MT & Sh & 2029 & Abundant on $\mathrm{W}$ shore \\
\hline & & & Ss & 2027 & Abundant on S \& E shore \\
\hline & & & Hy & 2028 & Scattered \\
\hline & & IP & $\mathrm{Sh}$ & 2031 & $\sim 200$ plants scattered \\
\hline & & ET & $\mathrm{Sh}$ & 2035 & $\sim 200$ plants scattered \\
\hline & & $\mathrm{BF}$ & Ss & 2026 & Abundant- 100,000 s of plants \\
\hline \multirow[t]{6}{*}{ Oct 2007} & WMWR & MT & $\mathrm{Sh}$ & 2315 & Common, widely distributed \\
\hline & & & Ss & 2316 & Common, widely distributed \\
\hline & & & Hy & 2317 & Common, scattered \\
\hline & & $\mathrm{BF}$ & Ss & 2313 & $\sim 100$ plants scattered \\
\hline & & $\mathrm{RD}$ & Ss & 2318 & $\sim 10,000$ s plants \\
\hline & & Pond $\mathrm{E}$ of RD & Ss & 2314 & $\sim 100$ plants scattered \\
\hline \multirow[t]{3}{*}{ Sep 008} & WMWR & MT & Sh & 2349 & Thinly scattered \\
\hline & & & Ss & 2350 & Thinly scattered \\
\hline & & & Hy & 2351 & $\begin{array}{l}\text { Concentrated along NW corner of } \\
\text { pond }\end{array}$ \\
\hline \multirow[t]{8}{*}{ Aug 2009} & WMWR & MT & $\mathrm{Sh}$ & 2391 & Uncommon, scattered \\
\hline & & & Ss & 2392 & Rare \\
\hline & & & Hy & 2393 & Common \\
\hline & & IP & Sh & 2395 & Uncommon, scattered \\
\hline & & QPL & Sh & 2406 & Rare \\
\hline & & & Ss & 2407 & Rare, scattered \\
\hline & & & Hy & 2408 & Uncommon, scattered \\
\hline & & $\mathrm{RD}$ & Ss & 2390 & Rare \\
\hline
\end{tabular}


Table continued

\begin{tabular}{|c|c|c|c|c|c|}
\hline Date & Area & Site & $\begin{array}{l}\text { Species } \\
\text { collected }\end{array}$ & *Collection \# & Abundance \\
\hline \multirow[t]{8}{*}{ Aug 2009} & FSMR & ET & $\mathrm{Sh}$ & 2397 & 30 plants, scattered \\
\hline & & EP & Sh & 2399 & 50 plants, scattered \\
\hline & & $\mathrm{ZP}$ & Sh & 2400 & Rare \\
\hline & & & Ss & 2401 & Rare \\
\hline & & & Hy & 2402 & Common \\
\hline & & PP & $\mathrm{Sh}$ & 2403 & Abundant \\
\hline & & & Ss & 2404 & Uncommon, scattered \\
\hline & & & Hy & 2405 & Abundant \\
\hline \multirow[t]{4}{*}{ Sep 2010} & WMWR & MT & $\mathrm{Sh}$ & 2459 & Rare \\
\hline & & & Hy & 2406 & Common \\
\hline & & $\mathrm{RD}$ & Ss & 2457 & $\begin{array}{l}\text { Uncommon, scattered; heavily } \\
\text { grazed }\end{array}$ \\
\hline & & GL & Ss & 2464 & Uncommon, scattered \\
\hline \multirow[t]{2}{*}{ Sep 2010} & FSMR & ET & $\mathrm{Sh}$ & 2462 & Uncommon, scattered \\
\hline & & PP & Hy & 2461 & $\sim 10,000$ s plants \\
\hline
\end{tabular}

*Collections were sent to one or more of the following herbaria: BRIT, MICH, MO, OKL, WISC, UMO 